\title{
EMOTION CARD DALAM USER PERSONA UNTUK MENINGKATKAN PERSEPSI PENGGUNA DALAM PENGGALIAN KEBUTUHAN PERANGKAT LUNAK
}

\author{
Wahyu Andhyka Kusuma1, Maulana Alan Gifary2, Rendy Wiranto Prasetya3, \\ Ahmad Fauzan Ali Syahbana4
}

${ }_{1}$ Prodi Informatika, Universitas Muhammadiyah Malang, Kota Malang, Indonesia 2 Prodi Informatika, Universitas Muhammadiyah Malang, Kota Malang, Indonesia 3 Prodi Informatika, Universitas Muhammadiyah Malang, Kota Malang, Indonesia 4 Prodi Informatika, Universitas Muhammadiyah Malang, Kota Malang, Indonesia

\begin{abstract}
Abstrak
Untuk meningkatkan sebuah system atau perangkat lunak (PL) yang dapat difungsikan dengan baik, maka perlu juga untuk menguasai dan memahami karateristik user yang akan berinteraksi dengan system atau PL ini. HCI disini adalah proses interaksi antara user dengan computer. Persona adalah teknik Human Computer Interaction (HCI) yang menggabungkan sebuah informasi tentang user untuk memahami karakteristik daripada user tersebut. Persoalan yang sering terjadi dalam interaksi user dengan komputer yaitu sering terjadinya salah pengertian dari user persona terhadap PL yang ada, sehingga bukan efektivitas dan efisiensi kerja yang diperoleh, akan tetapi justru menyebabkan pekerjaan tidak efisien dan efektiv, user sering mengalami kesulitan menggunakan PL tersebut karena tidak familiar dengan PL, PL juga terlalu rumit sehingga sulit dipelajari, PL tidak sesuai dengan kebutuhan pengguna dan tidak atau belum mengakomodasi kebutuhan yang penting bagi pengguna. Tujuan penelitian dilakukan untuk mendapatkan berbagai perspektif penggunaan PL sesuai dengan karakteristik pengguna, sehingga rancangan kebutuhan PL diharapkan dapat mewakili dari berbagai macam tipe pengguna.
\end{abstract}

\begin{abstract}
To improve a system or software (PL) that can function properly, it is also necessary to master and understand the characteristics of users who will interact with this system or PL. HCI here is the process of interaction between users and computers. Persona is a Human Computer Interaction (HCI) technique that combines information about a user to understand the characteristics of that user. The problem that often occurs in user interaction with computers is that there is often a misunderstanding of the user persona of existing software, so that it is not the effectiveness and efficiency of work obtained, but instead causes inefficient and effective work, users often have difficulty using the software because it is not familiar with PL, PL is too complex so it is difficult to learn, PL is not according to user needs and does not or does not accommodate needs that are important to users. The purpose of the study was conducted to obtain various perspectives on the use of software according to user characteristics, so that the design of software needs is expected to be able to represent various types of users.
\end{abstract}

Kata Kunci:

Persona, Human Computer Interaction (HCI), Perangkat Lunak (PL)

\section{Keywords:}

Persona, Human Computer Interaction (HCI), Perangkat Lunak (PL)

\footnotetext{
* Korespondensi

E-mail: kusuma.wahyu.a@gmail.com
} 


\section{PENDAHULUAN}

Zaman sekarang Interaksi komputer manusia (HCI) menggunakan proses dan Teknik pengembangan untuk memastikan bahwa kegunaan produk perangkat lunak memenuhi persyaratan minimum. Teknik Personas yaitu mengumpulkan, menganalisis dan mensintesis informasi terkait dengan pengguna yang berinteraksi dengan sistem perangkat lunak. Teknik ini membantu memfokuskan analisis dan desain perangkat lunak pada fitur dan tujuan pengguna akhir (Acuña, Castro \& Juristo, 2012).

Komunitas Human-Computer Interaction (HCI) beragam. Konferensi Association for Computing Machinery (ACM) Computer Human Interaction (CHI) adalah konferensi terbesar dan bisa dibilang salah satu konferensi terpenting di lapangan, yang diselenggarakan melalui Interaksi Manusia Komputer Kelompok Minat Khusus (SIGCHI). Pada pertemuan keanggotaan SIGCHI 2005, organisasi konferensi berikutnya dibahas, yang memicu pertandingan teriakan antara akademisi dan praktisi (Arnowitz \& Dykstra-Erickson, 2005). Pecahnya emosi ini menggambarkan ketegangan antara kelompok-kelompok yang berbeda dan itu dapat dijelaskan dengan melihat lebih dekat pada paradigma di mana mereka beroperasi. Sudah sekitar sepuluh tahun yang lalu Rogers, Bannon dan Button (Rogers, Bannon, \& Button, 1994) Membuka dan membahas tiga pertanyaan utama: (1) Apa masalah di [atau dengan] HCI? (2) Apa yang ditawarkan oleh pendekatan teoretis HCI? (3) Bagaimana hubungan teori dengan praktik? Dalam makalah terprogram ini dalam penelitian akan membahas, mendiskusikan dan memberikan jawaban yang mungkin untuk ketiga pertanyaan ini (Rauterberg, 2006).

Persona adalah "arketipe hipotetis pengguna nyata (Copper, 1999)." Mereka didasarkan pada pemahaman empiris karakteristik pengguna, dan perilaku. Meskipun masih agak kontroversial (Chapman \& Milham, 2006), (Marshall, 2003) mereka menikmati popularitas yang cukup besar sebagai teknik desain yang kuat. Persona telah digunakan secara luas Selain itu, dalam penelitian ini dirancang dan diimplementasikan alat prototipe untuk mendukung teknik Personas yang diusulkan. Personas yang ditingkatkan menghindari rintangan yang dihadapi oleh pengembang perangkat lunak biasa yang tidak terbiasa dengan teknik HCI yang menerapkan Personas asli. Berdasarkan pengamatan bermanfaat untuk mengadaptasi Personas untuk diintegrasikan ke dalam proses pengembangan SE. Integrasi Personas ke tahap persyaratan SE dapat meningkatkan pemahaman tentang apa yang harus dilakukan produk perangkat lunak dan bagaimana seharusnya berperilaku. Teknik Personas muncul untuk membantu memfokuskan analisis perangkat lunak dan kegiatan desain pada karakteristik dan tujuan pengguna akhir. dan telah diperkaya proses persyaratan SE dengan memasukkan kegiatan Personas ke dalam kegiatan persyaratan. Elisitasi persyaratan dan analisis persyaratan adalah kegiatan rekayasa persyaratan yang paling dipengaruhi oleh penggabungan Personas.

\section{METODE}

State Hypotheses, metode pada kegiatan pertama ini dilakukan untuk menyatakan hipotesis awal tentang kemungkinan persona yang akan dibuat. Untuk menggali hipotesis tersebut dilakukan wawancara dan penggalian informasi melalu stakeholder.

Identify Behavioral Variables, metode dalam kegiatan kedua ini di lakukan untuk mengiidentifikasi dan mengukur berdasarkan survei dan wawancara mendalam, dan dibuat karakteristik fiksi dari orangorang yang angka latar belakang untuk pengguna, tujuan penggunaan, kebutuhan, sikap, dan pengetahuan dan kemahiran khusus, dan lain-lain (Kim).

Map Interview Subjects to Behavioral Variables, metode dalam kegiatan ketiga ini di lakukan untuk menghasilkan subject dari variable berdasarkan karakteristik atau tingkah laku agar memudahkan dalam mengidentifikasi lebih mendalam dengan stakeholder, variable tersebut akan dikumpulakan dan dilakukan pemetaan subjek wawancara, setelah terkumpul variable dari berbagai aspek akan dilakukan mapping/menyusun dangan rentang tertentu sesuai tingkah laku atau karakteristik stakeholder (Acuña, Castro \& Juristo, 2012).

Identify Significant Behavior Patterns, metode dalam kegiatan ke empat ini di lakukan untuk melakukan pengelompokan variable dari tingkah laku atau karateristik menjadi subjek kelompok, kesamaan signifikan menjadi fokus narasi variable yang di hasilkan (Marsden \& Haag, 2016).

Synthesize Characteristic and Relevant Goals, metode dalam kegiatan kelima ini di lakukan untuk mengsintesis karakteristik dan tujuan yang relevan dan juga menjelaskan kepribadian dari stakeholder yang telah diwawancarai untuk mendapatkan pola pola karakterisitik atau prilaku yang lebih rinci berdasarkan wawancara (Bagriyanik \& Karahoca, 2014).

Check for Redudancy and Completeness, metode dalam kegiatan ke enam ini di lakukan untuk proses pengecekan dari kegiatan pertama hingga kegiatan kelima sehingga menghasilkan validasi dokumen dari sebuah pemetaan pada kepribadian dan juga karateristik. 
Expand the Description of Attributes and Behaviours, metode dalam kegiatan ketujuh ini di lakukan untuk mendeskripsikan stakeholder yang sudah di wawancari untuk mendapatkan personas foundation document berupa gambaran personas dan menghasilkan beberapa karateristik yang harus di rinci (Pruitt, John \& Adlin, 2010).

Designate Persona Types, metode dalam kegiatan kedelapan ini di lakukan untuk menemukan suatu persona utama yang kebutuhan dan tujuan nya dapat sepenuhnya dan memiliki respon positif oleh satu antarmuka (Muniraj \& Jagannatha, 2007).

Build Use Case, Metode dalam kegiatan kesembilan ini di lakukan untuk membuat diagaram use case beranotasi dan juga membuat penjelasan detail use case.

Implement and Evaluate Prototypes, metode dalam kegiatan kesepuluh ini untuk membuat prototipe dari diagram use case, prototipe sangat penting untuk menguji sebuah kelayakan produk yang dibuat setelah melalui kegiatan satu sampai dengan kegiatan kesembilan, tujuannya untuk mengevaluasi hasil kerja.

\section{HASIL DAN PEMBAHASAN}

\section{A. Activity 1 - Hypotesis Table}

Tabel 1 menunjukkan mahasiswa tidak mengetahui beberapa matakuliah berprasyarat saat melakukan pemrograman krs. Tujuan dari tahap ini adalah untuk mengidentifikasi persona yang memiliki hubungann dengan permasalahan, untuk mengetahui perbedaan antara pengguna berdasarkan kebutuhan dan perilaku mereka.

\section{B. $\quad$ Activity 2 - Range of Behavioural Variable}

Pada Tabel 2 dan Tabel 3 ini hasil dari observasi perilaku persona Mahasiswa dan Dosen berdasarkan permasalahan yang ada dijabarkan dengan menggunakan skala variabel.

C. Activity 3 - Mapping of Interview Subject (SignificantBehaviour)/(Mahasiswa) and (Significant Behaviour)/(Dosen)

Pada Gambar 1 dan Gambar 2 ini dilakukan pemetaan berdasarkan hasil interview sesuai skala variabel agar dalam analisanya lebih mudah untuk dikelompokkan karena sudah dipetakan sesuai dengan variabel perilaku yang diamati.

Tabel 1. Hypotesis Table

\begin{tabular}{|c|c|c|}
\hline Hypotesis & Persona & Explanation \\
\hline $\mathrm{H}_{0}$ & Mahasiswa & $\begin{array}{l}\text { Mahasiswa tidak mengetahui Mata Kuliah dasar } \\
\text { menjadi syarat untuk mengambil beberapa Mata } \\
\text { Kuliah didalam pemrograman studi. }\end{array}$ \\
\hline $\mathrm{H}_{1}$ & Dosen Wali & $\begin{array}{l}\text { Beberapa dosen wali tidak memberikan dorongan } \\
\text { kepada mahasiswa untuk berkonsultasi sebelum } \\
\text { melakukan pemrograman krs. }\end{array}$ \\
\hline
\end{tabular}

Tabel 2. Range of Behaviour Variable Mahasiswa

\begin{tabular}{ll}
\hline \multicolumn{1}{c}{ Observed Behavioural Variabel } & \multicolumn{1}{c}{ Scale } \\
\hline Mengetahui mata kuliah yang memiliki prasyarat. & Tau $\leftrightarrow$ Tidak Tau \\
Frekuensi melakukan konsultasi dosen wali. & Selalu $\leftrightarrow$ Kadang-kadang $\leftrightarrow$ Tidak Pernah \\
Alasan melakukan/tidak konsultasi dosen wali. & Dorongan dosen $\leftrightarrow$ Tidak Keduanya $\leftrightarrow$ Tidak Penting \\
\hline
\end{tabular}

Tabel 3. Range of Behaviour Variable Dosen

\begin{tabular}{ll}
\hline \multicolumn{1}{c}{ Observed Behavioural Variabel } & \multicolumn{1}{c}{ Scale } \\
\hline Frekuensi melakukan konsultasi. & Selalu $\leftrightarrow$ Sering \\
Frekuensi tidak melakukan konsultasi. & Tidak Pernah $\leftrightarrow$ Kadang-kadang $\leftrightarrow$ Sering \\
Motivasi melakukan konsultasi. & Rutinitas $\leftrightarrow$ Memberikan informasi penting $\leftrightarrow$ Mahasiswa \\
& asal-asalan ketika memprogram KRS
\end{tabular}




\begin{tabular}{ll}
\hline \multicolumn{1}{c}{ Observed Behavioural Variabel } & \multicolumn{1}{c}{ Scale } \\
\hline Motivasi tidak melakukan konsultasi & $\begin{array}{l}\text { Tidak Ada } \leftrightarrow \text { Mahasiswa tidak kooperatif } \leftrightarrow \text { Sibuk(alasan } \\
\text { pribadi) }\end{array}$ \\
\hline
\end{tabular}

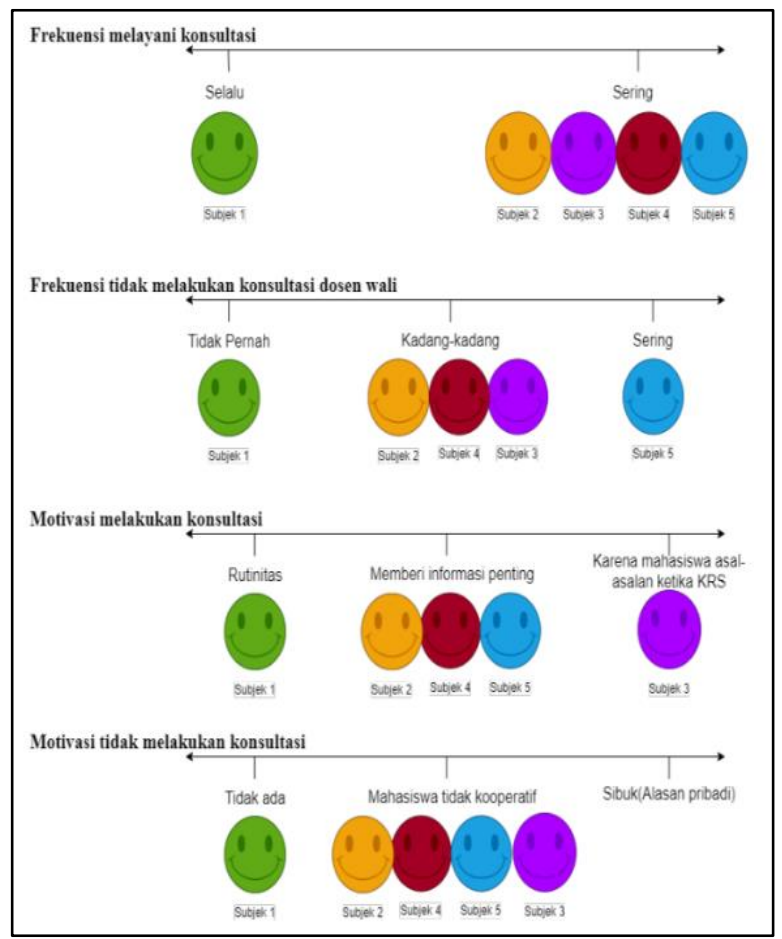

Gambar 1. Mapping of Interview Subject Mahasiswa,

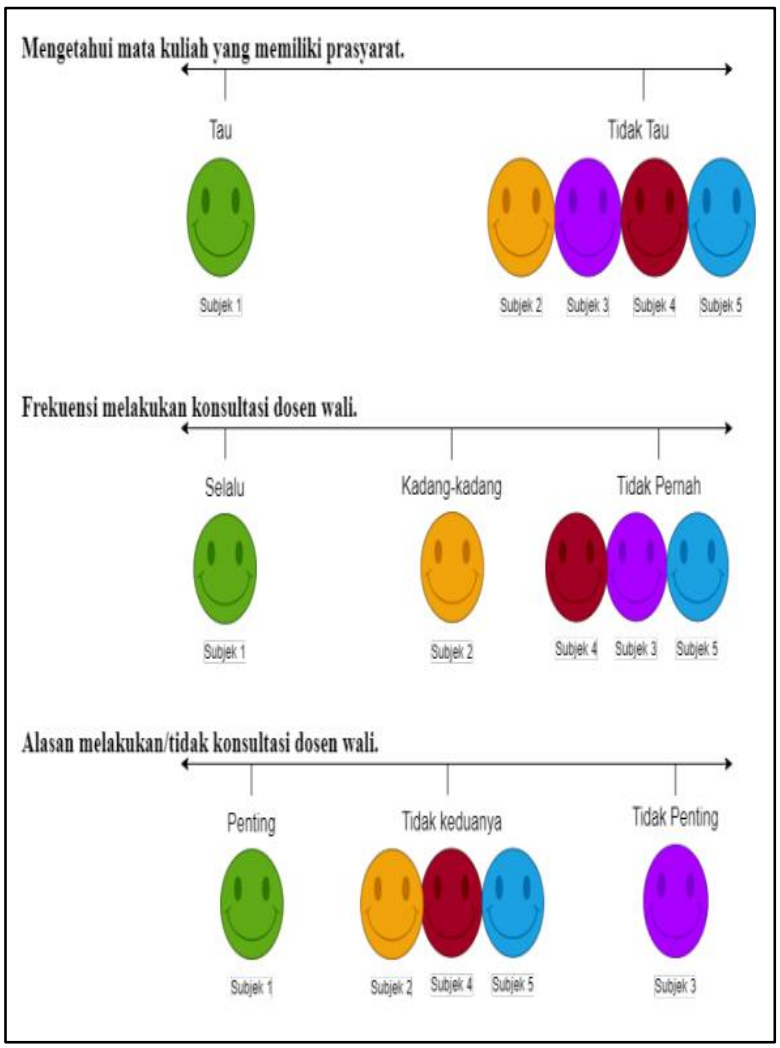

Gambar 2. Mapping of Interview Subject Dosen 


\section{Activity 4 - Identify Significant Behavior Patterns}

Pada tahap ini dilakukan pemetaan pengamatan berdasarkan variabel dan jumlah jawaban setiap persona, sehingga menghasilkan presentase sesuai banyaknya jawaban di interview pada Tabel 4 , Tabel 5 dan Gambar 3 dan Gambar 4.

Tabel 4. Percentage Grouping Table Mahasiswa

\begin{tabular}{|c|c|c|}
\hline Observed Behavioural Variabel & Scale & Percentage \\
\hline \multirow{2}{*}{ Mengetahui mata kuliah yang memiliki prasyarat } & Tau & $20 \%$ \\
\hline & Tidak Tau & $80 \%$ \\
\hline \multirow{3}{*}{ Frekuensi melakukan konsultasi dosen wali } & Selalu & $20 \%$ \\
\hline & Kadang-kadang & $20 \%$ \\
\hline & Tidak Pernah & $60 \%$ \\
\hline \multirow{2}{*}{ Alasan melakukan/tidak konsultasi dosen wali } & Penting & $20 \%$ \\
\hline & Tidak Keduanya & $60 \%$ \\
\hline
\end{tabular}

Tabel 5. Percentage Grouping Table Dosen

\begin{tabular}{llc}
\hline \multicolumn{1}{c}{ Observed Behavioural Variabel } & \multicolumn{1}{c}{ Scale } & Percentage \\
\hline \multirow{2}{*}{ Mengetahui mata kuliah yang memiliki prasyarat } & Selalu & $20 \%$ \\
& Sering & $80 \%$ \\
& Tidak Pernah & $20 \%$ \\
Frekuensi melakukan konsultasi dosen wali & Kadang-kadang & $60 \%$ \\
& Sering & $20 \%$ \\
& Rutinitas & $20 \%$ \\
\multirow{2}{*}{ Alasan melakukan/tidak konsultasi dosen wali } & Memberi Informasi Penting & $60 \%$ \\
& Karena Mahasiswa Asal - & $20 \%$ \\
& asalan Ketika KRS & $20 \%$ \\
\multirow{2}{*}{ Motivasi TIdak Melakukan Konsultasi } & Tidak Ada & $80 \%$ \\
& Mahasiswa Tidak Kooperatif & $0 \%$ \\
\hline
\end{tabular}

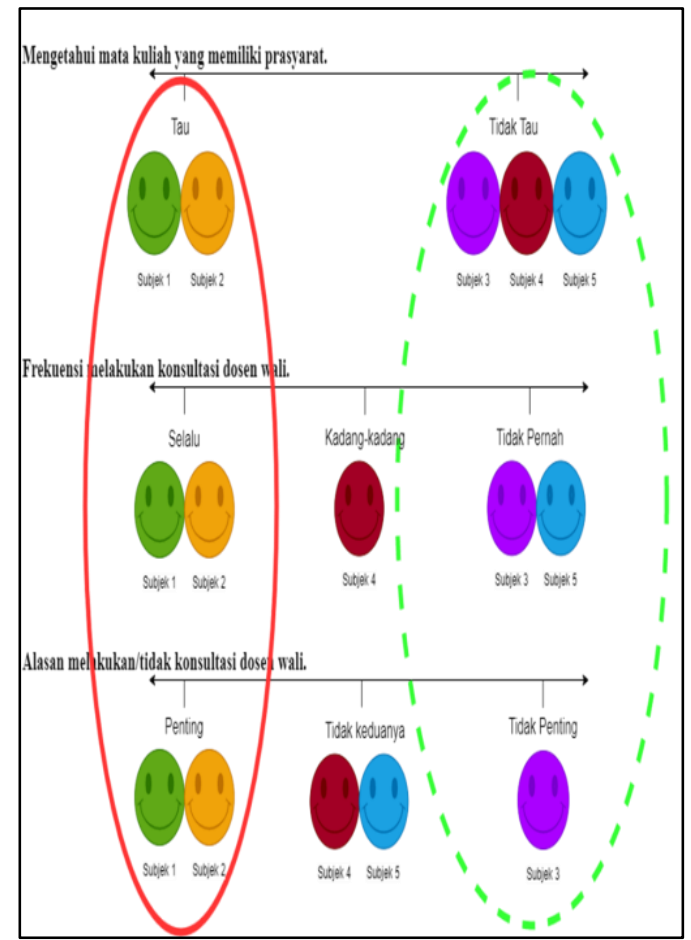

Gambar 3. Identify Significant Behaviour Patterns Mahasiswa, 


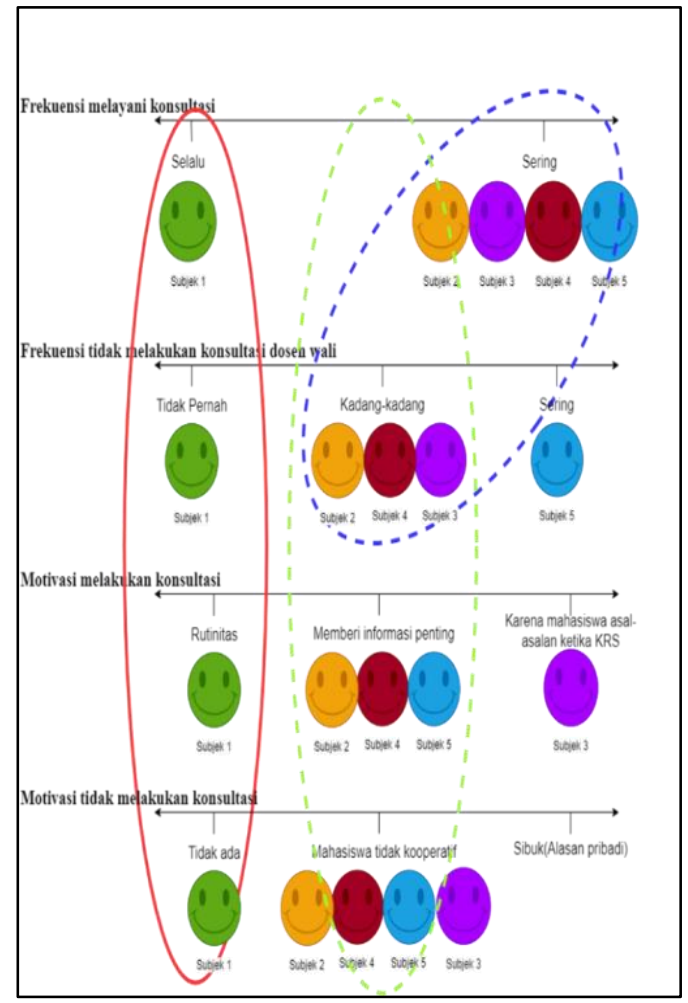

Gambar 4. Identify Significant Behaviour Patterns Dosen

\section{E. Activity 5 - Synthesize Characteristics and Relevant Goals}

Pada Tahap ini menjelaskan hasil wawancara berupa karakteristik user dan tujuan yang berguna untuk menyempurnakan perangkat lunak, hasil ini dibutuhkan untuk membuat Persona Identification, bisa di lihat pada Gambar 5 dan Gambar 6.

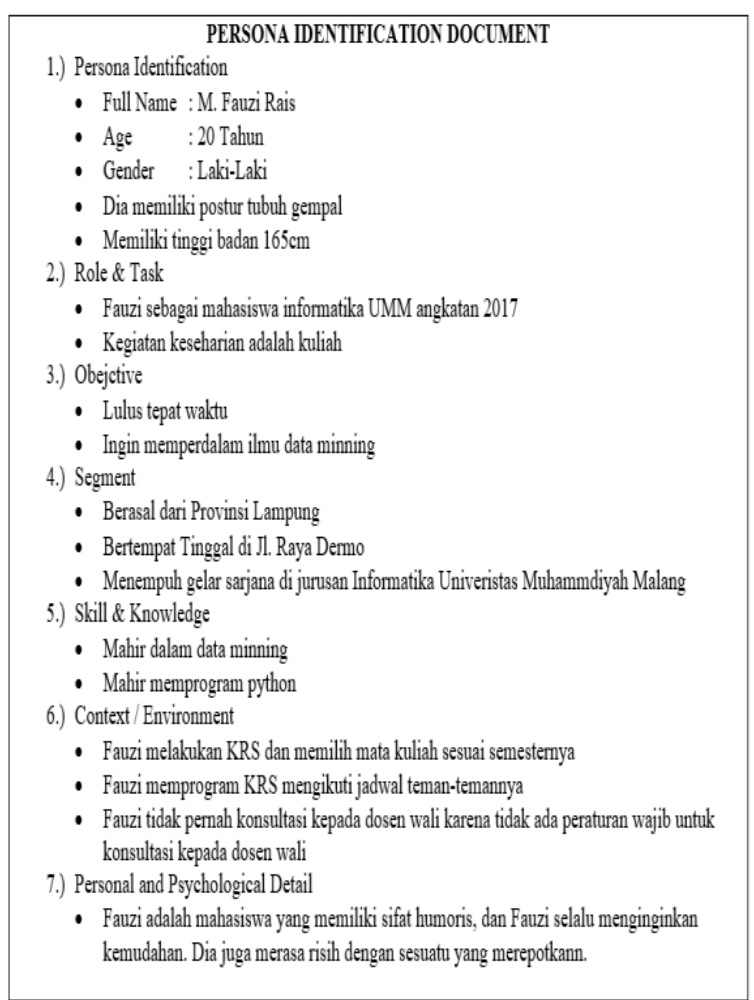

Gambar 5. Persona Identification Document Mahasiswa 


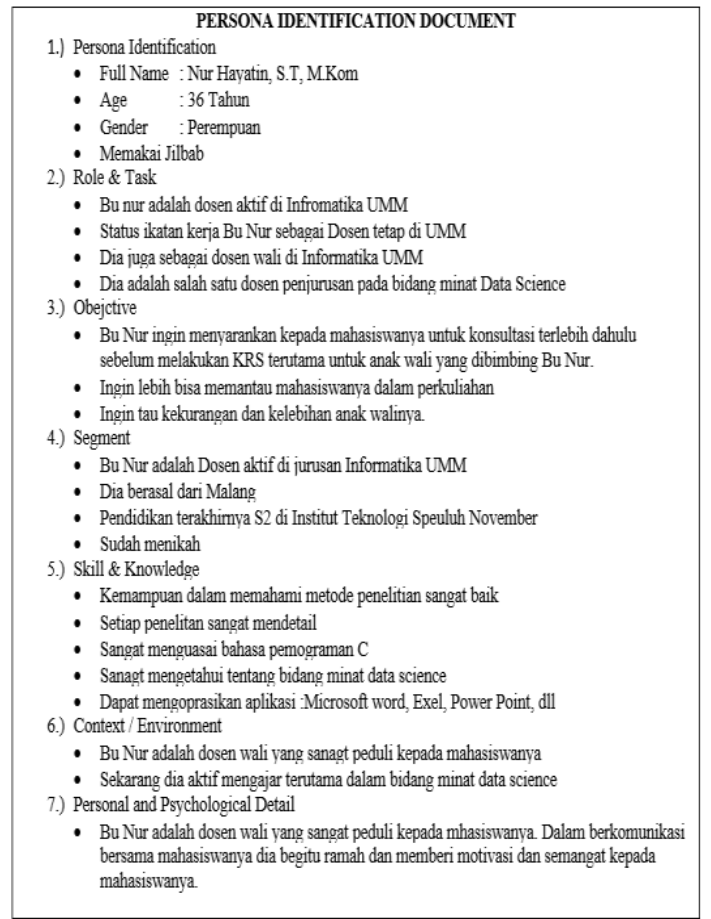

Gambar 6. Persona Identification Document Dosen

\section{F. Activity 6 - Check for Redundancy and Completeness}

Pada tahap ini Dilakukan Proses Validasi 4 Fase, yang dimana bertujuan untuk mengecek jika terdapat kesalahan atau kekurangan, maka dapat dilakukan penelitian tambahan. Untuk tahap validasinya ada pada Tabel 6.

Tabel 6. Validasi Document

\begin{tabular}{|c|c|}
\hline Pertanyaan & Hasil \\
\hline $\begin{array}{l}\text { Mengecek apakah Seluruh Subject yang } \\
\text { terlibat sudah mengisi? }\end{array}$ & $\begin{array}{l}\text { Sudah, karena semua responden mengisi sesuai kriteria dan } \\
\text { permasalahan mereka masing-masing. }\end{array}$ \\
\hline Memvalidasi terhadap responden lain? & $\begin{array}{l}\text { Perlu, dikarenakan proses validasi terhadap responden lain } \\
\text { dapat memenuhi kriteria dari jawaban variable-variable yang } \\
\text { terkait, dan menjadi informasi dasar identifikasi dari awal } \\
\text { permasalahan. }\end{array}$ \\
\hline $\begin{array}{l}\text { Mengecek apakah variable yang dibuat } \\
\text { telah memenuhi dari jawaban dan } \\
\text { permasalah dalam emoticon card? }\end{array}$ & $\begin{array}{l}\text { Sudah memenuhi, karena terlihat dari jawaban respondent } \\
\text { dari proses validasinya memiliki jawaban yang relevan, } \\
\text { sehingga telah menjawab proses identifikasi masalah. }\end{array}$ \\
\hline $\begin{array}{l}\text { Meanalisa apakah terdapat anomaly yang } \\
\text { terjadi terhadap responden? dan } \\
\text { bagaimana anomaly tersebut terjadi? }\end{array}$ & $\begin{array}{l}\text { Ada, karena ada beberapa subject yang meiliki hasil yang } \\
\text { tidak signifikan berdasarkan data pada variable. Pertama } \\
\text { pada subject } 3 \text { yang mempunyai alasan tidak penting untuk } \\
\text { melakukan konsultasi terhadap dosen wali dikarenakan dia } \\
\text { tidak mengetahui tentang mata kuliah berprasyarat dan tidak } \\
\text { pernah melakukan konsultasi terhadpap dosen wali. } \\
\text { Sedangkan untuk subject } 4 \text { mempunyai ambigu dalam } \\
\text { melakukan konsultasi kepada dosen wali, walaupun dia } \\
\text { kadang-kadang melakukan konsultasi terhadap dosen wali } \\
\text { namun alasan dia untuk melakukan konsultasi adalah } \\
\text { netral/tidak keduanya. }\end{array}$ \\
\hline
\end{tabular}

Kesimpulan: persona yang ditampilkan sudah tepat dan memiliki perbedaan yang lumayan signifikan tergantung kebutuhan setiap personanya dan karakteristik masing masing persona, oleh karena itu, tidak dibutuhkan pembuatan perona baru, karena sudah memenuhi kebutuhan stakeholder. 


\section{G. Activity 7 - Expand the Description of Attributes and Behaviours}

Mendeskripsikan Profil dari tiap Stake Holder. Contoh dari pendeskripsian dari tiap stake holder bisa di lihat pada Tabel 7 dan Tabel 8 .

Tabel 7. Narasi Persona

\begin{tabular}{ll}
\hline \multicolumn{1}{c}{ Nama } & \multicolumn{1}{c}{ Deskripsi } \\
\hline & Fauzi (20) mahasiswa informatika angkatan 2017 yang sekrang \\
berada di semester 6. Fauzi berasal dari pulau Lampung, kini ia \\
sedang mendalami pada matakuliah database. Fauzi melakukan \\
KRS dan memilih mata kuliah sesuai sks di semesternya, \\
mengambil matakuliah yang di wajbkan dan mengambil \\
matakuliah yang di luar sks jika masih memungkinkan, dia juga \\
memprogram KRS mengikuti jadwal teman-temannya. Dan Fauzi \\
tidak pernah konsultasi kepada dosen wali karena tidak ada \\
peraturan wajib untuk konsultasi kepada dosen wali \\
\\
Nur Hayatin (36) adalah seorang dosen aktif di informatika UMM, \\
Nur Hayatin juga sebagai dosen wali di informatika, dia sangat \\
memperhatikan mahasiswanya, Nur Hayatin adalah salah satu \\
dosen dalam bidang minat Data Science, kemampuan iNur \\
Hayatin dan program sangat handal dan juga sangat handal \\
dalam metode penelitian. Nur Hayatin sebagai dosen wali ingin \\
menyarankan kepada mahasiswa untuk konsultasi terlebih \\
dahulu sebelum melakukan KRS terutama untuk anak wali yang \\
dibimbing Nur Hayatin.
\end{tabular}

\section{H. Activity 8 - Designate Persona Types}

Pada tahap ini menggambarkan tipe persona secara rinci mengenai informasi dan karakteristiknya. Persona ini dtampilkan secara menarik pada Gambar 7 dan Gambar 8.

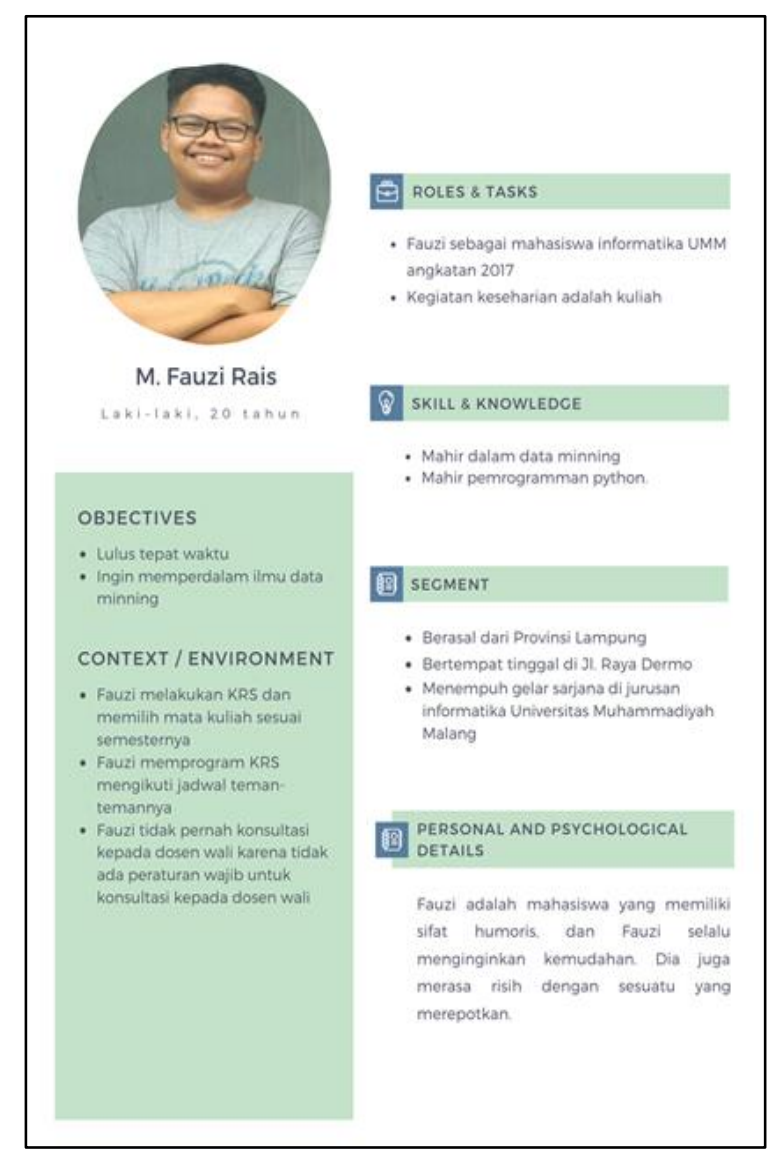

Gambar 7. Desain User Persona Mahasiswa, 


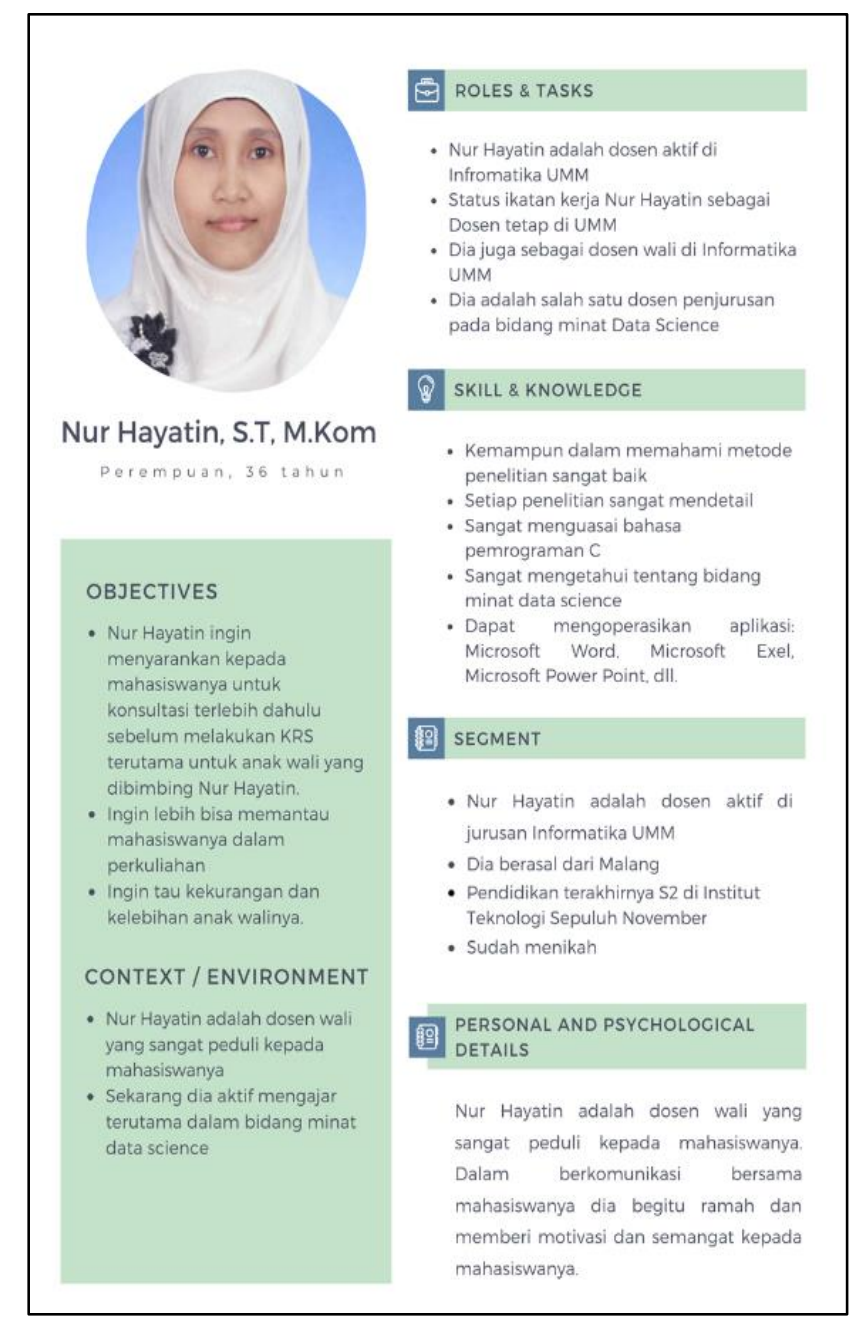

Gambar 8. Desain User Persona Dosen

\section{Activity 9 - Build Use Case}

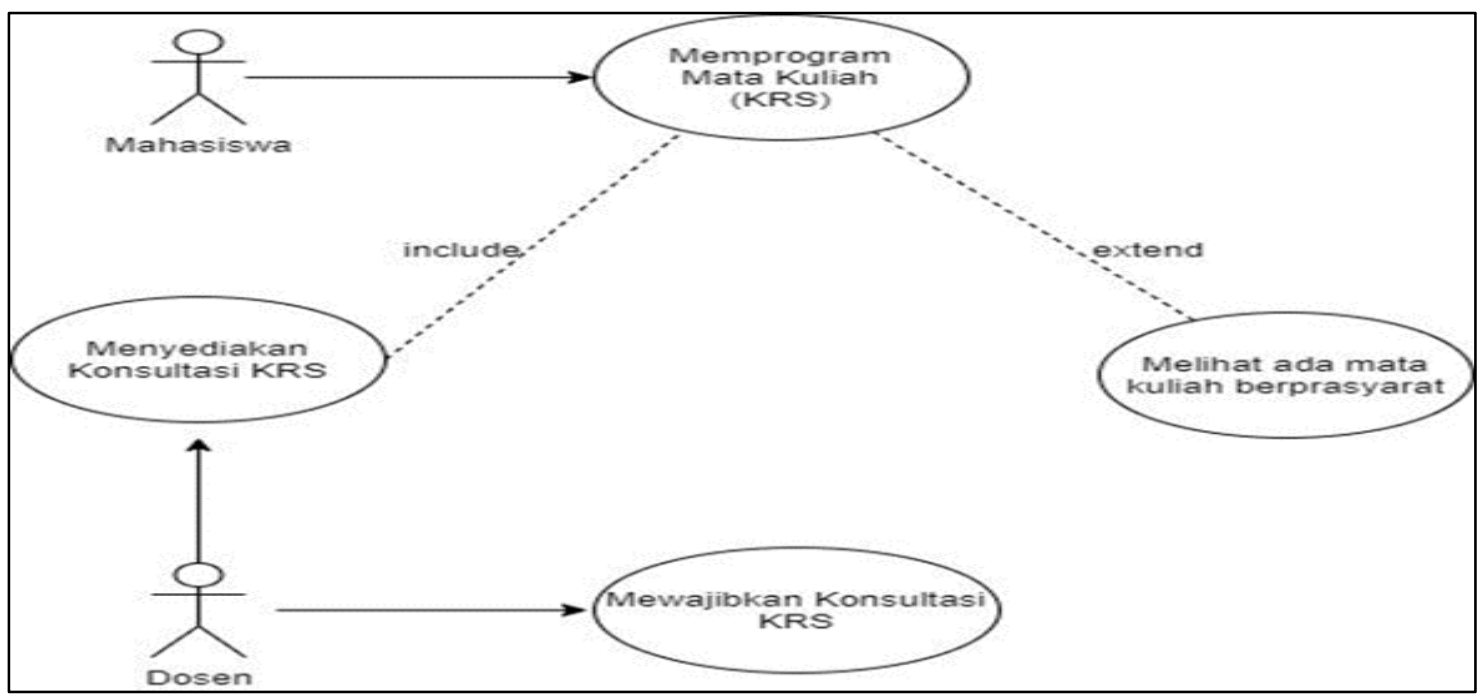

Gambar 9. Use Case 


\section{J. Activity 10 - Implement and Evaluate Prototype}

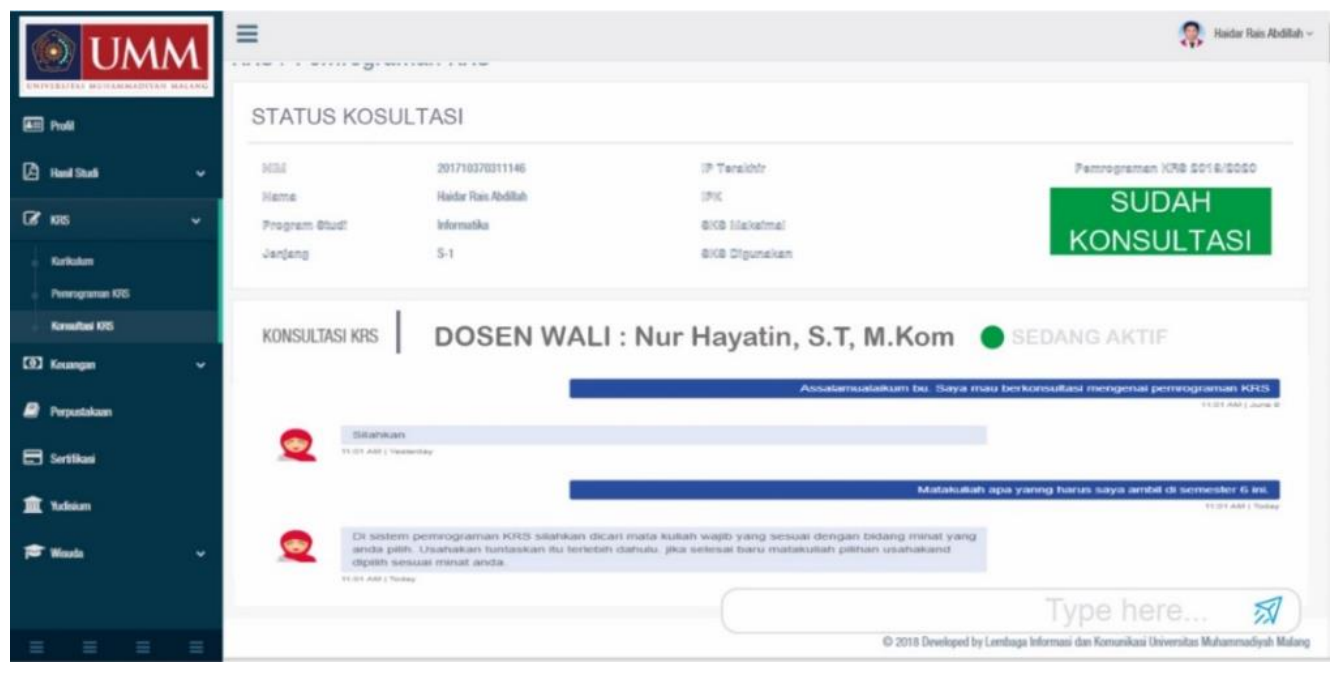

Gambar 10. Prototype

Penjelasan Gambar 10 diatas, Halaman konsultasi disini mahasiswa melakukan konsultasi ke dosen wali. Jika sudah konsultasi maka bisa memprogram KRS.

\section{SIMPULAN DAN SARAN}

Dari penelitian ini disimpulkan bahwa mahasiswa yang menemukan solusi dari permasalahan di atas bukan solusi yang berasal dari perangkat lunak atau sistem yang disebut INFOKHS, jadi dalam penelitian ini ditemukan solusi berupa tampilan yang sudah disinkronisasi dengan pengalaman user dan juga kebutuhan user yang telah berhadapan langsung dengansistem INFOKHS.

\section{Daftar Pustaka}

Acuña, S. T., Castro, J. W., \& Juristo, N. (2012). A HCI technique for improving requirements elicitation. Inf. Softw. Technol.Vol. 54, No. 12, pp. 1357-1375.

Arnowitz, J. \& Dykstra-Erickson, E. (2005). CHI and the practitioner dilemma. Interactions. Vol. 12, No. 4, p. 5.

Bagriyanik, S. and Karahoca, D. (2014). System analyst expectations from requirements engineering tools: A human computer interaction perspective. Glob. J. Comput. Sci. Vol. 04, No. 1, pp. 7-16.

Chapman, C. N. and Milham, R. P. (2006). The personas' new clothes: Methodological and practical arguments against a popular method. Proc. Hum. Factors Ergon. Soc. No. April, pp. 634-636.

Copper, A. (1999). The Inmates Are Running the Asylum: Why High-Tech Products Drive Us Crazy and How to Restore the Sanity. ISBN:, pp. 0--citation\_lastpage.

Kim, G. Develop the System for the protection of valuable contents.

Marsden, N. and Haag, M. (2016). Stereotypes and politics: Reflections on personas. Conf. Hum. Factors Comput. Syst. - Proc., no. May, pp. 4017-4031.

Marshall, C. (2003). The trouble with scenarios and personas. Retrieved the, vol. 21.

Muniraj, G. and Jagannatha, V. (2007). Requirements engineering using prototyping projects in healthcare diagnostic software applications. Proc. - 15th IEEE Int. Requir. Eng. Conf. RE 2007, no. January 2007, pp. 307-312.

Pruitt, T., John and Adlin. (2010). The persona lifecycle: keeping people in mind throughout product design. Elsevier.

Rauterberg, M. (2006). HCI as an engineering discipline: to be or not to be!? African J. Inf. Commun. Technol. Vol. 2, No. 4, pp. 163-184.

Rogers, Y. Liam, B., and Button, G. (1994). Rethinking theoretical frameworks for HCI: report on an INTERCHI'93 workshop, Amsterdam, 24--25th April, 1993. ACM SIGCHI Bull. Vol. 26, pp. 28-30. 